\title{
EFEKTIVITAS PENGGUNAAN E-LEARNING BERBASIS GOOGLE CLASROOM UNTUK MENINGKATKAN MOTIVASI BELAJAR BIOLOGI (LINTAS MINAT) SISWA KELAS XI IPS-1 SMA NEGERI 1 MASBAGIK
}

\author{
Baiq Bunayati Sholihan \\ SMA Negeri 1 Masbagik \\ E-mail: baiqbunayatisholihan@gmail.com
}

\begin{abstract}
Abstrak
Kondisi pandemic covid-19 yang mengharuskan menerapkan Pysical distencing sehingga pembelajaran tatap muka tidak bisa dilakukan dan terpaksa pembelajaran dilakukan secara online (daring) dan masih rendahnya motivasi siswa dalam belajar biologi. Penelitian tindakan kelas ini bertujuan untuk meningkatkan motivasi belajar biologi siswa kelas XI IPS-1 SMAN 1 Masbagik dan mendeskripsikan peningkatan motivasi belajar biologi siswa kelas XI IPS-1 SMAN 1 Masbagik melalui E-Learning berbasis Google Classroom. Metode penelitian yang digunakan adalah penelitian tindakan kelas. Penelitian ini dilakukan dalam dua siklus terhadap 30 orang siswa. Teknik pengumpulan data melalui observasi dan angket motivasi. Keterlaksanaan E-Learning berbasis Google Classroom dinyatakan dengan kategori sangat baik, baik, cukup baik, kurang baik, dan tidak baik, sedangkan motivasi belajar matematika dinyatakan dengan kategori sangat tinggi, tinggi, sedang, rendah dan sangat rendah. Berdasarkan hasil penelitian yang dilakukan dapat disimpulkan hal-hal sebagai berikut: 1) keterlaksanaan E-Learning bebasis Google Classroom pada siklus I pada kategori cukup baik dan pada siklus II pada kateori baik. 2) Motivasi belajar biologi siswa kelas XI IPS-1 SMA Negeri 1 Masbagik pada siklus I rendah, siklus dua sedang, yaitu pada siklus I rata-rata motivasi belajar biologi adalah $66,3 \%$ sedangkan pada siklus II naik menjadi $72,4 \%$.
\end{abstract}

Kata kunci: E-Learning, Google Classroom, MotivasiBelajarBiologi

Abstract

The condition of the covid-19 pandemic that requires applying physical distancing so that face-to-face learning cannot be done and learning is forced to be done online (online) and students' motivation to learn biology is still low. This classroom action research aims to increase students' motivation to learn biology in class XI IPS-1 at SMAN 1 Masbagik and describe the increase in motivation to learn biology at class XI IPS-1 at SMAN 1 Masbagik through Google Classroom-based E-Learning. The research method used is classroom action research. This research was conducted in two cycles of 30 students. Data collection techniques through observation and motivation questionnaires. The implementation of E-Learning based on Google Classroom is stated in the very good, good, quite good, poor, and not good categories, while the motivation to learn mathematics is stated in the very high, high, medium, low and very low categories. Based on the results of the research conducted, it can be concluded as follows: 1) the implementation of E-Learning based on Google Classroom in the first cycle in the fairly good category and in the second cycle in the good category. 2) Biology learning motivation of students in class XI IPS-1 SMA Negeri 1 Masbagik in the first cycle is low, the second cycle is moderate, namely in the first cycle the average motivation to learn biology is $66.3 \%$ while in the second cycle it increases to $72.4 \%$.

Keywords: E-Learning, Google Classroom, Motivation to Study Biology 


\section{PENDAHULUAN}

Pendidikan merupakan salah satu bagian yang tidak terpisahkan dari proses pengembangan bangsa. Melalui Pendidikan diharapkan dapat merubah pola piker manusia menjadi lebih luas dan tingkah laku yang berkualitas. Pada abad ke-21 telah terjadi berbagai perkembangan ilmu pengetahuan dan teknologi yang sangat pesat. Hal ini ditandai dengan adanya teknologi informasi dan komunikasi yang menyebar secara cepat dan luas dalam setiap bagian kehidupan termasuk dalam dunia pendidikan. Dalam bahasa sederhana, teknologi informasi dan komunikasi adalah medium interaktif yang digunakan untuk berkomunikasi jarak jauh dalam rangka tukarmenukar informasi (Alam, 2012).

Terjadinya perkembangan ilmu pengetahuan dan teknologi dalam dunia pendidikan, menuntut guru untuk lebih kreatif dan inovatif dalam proses kegiatan pembelajaran agar tercapainya tujuan dari pembelajaran. Ketika pemerintah memberlakukan masa belajar, bekerja dan beribadah darirumah, akibat adanya corona virus atau yang dikenal dengan istilah covid-19 yang melanda bangsa didunia sejak awal tahun 2020, pemberlakuan pembelajaran yang tadinya dilaksanakan disekolah, tiba-tiba berpindah dilaksanakan dirumah. Kebijakan ini mengakibatkan peroses kegiatan belajar mengajar tidak lagi dilakuak di kelas tetapi dialihkan ke rumah. Kondisi ini memaksa guru harus menyiapkan pembelajaran secara online. Maka seiring dengan kegiatan pembelajaran online dalam seketika guru dipaksa mengubah model pembelajaran yang biasa tatap muka dialihkan dengan daring. Menanggapi hal itu, E-Learning sebagai metode pembelajaran baru dalam pendidikan memberikan peran dan fungsi yang besar bagi dunia pendidikan yang selama ini dibebankan dengan banyaknya kekurangan dan kelemahan pendidikan konvensional (pendidikan pada umumnya) diantaranya adalah keterbatasan ruang dan waktu dalam peroses pendidikan konvensional (Hakim, 2016).

Teknologi informasi yang mempunyai standar platform internet yang bisa menjadi solusi permasalahan tersebut karena sifat dari internet itu sendiri yaitu memungkinkan segala sesuatu saling terhubung. Pembelajaran E-Learning dalam penelitian sebelumnya yang dilakukan Arends, menggunakan beberapa system E-Learning untuk mendukung peroses belajar dan mengajar. Sistem E-Learning yang digunakan yaitu LMS Modle, tetapi E-Learning ini kurang dimanfaatkan secara optimal (Arends, 2008). Pentingnya biologi dalam kehidupan sehari-hari mungkin belum banyak dirasakan oleh siswa khususnya jurusan IPS, sehingga siswa kurang termotivasi dalam belajar biologi. Berdasarkan hasil pengamatan di kelas XI IPS-1 SMA Negeri 1 Masbagik, ketika pembelajaran berlangsung perhatian siswa kurang, respon siswa masih rendah, dan aktivitas siswa kurang. Pada pengamatan pembelajaran di kelas tersebut, beberapa siswa kurang memperhatikan penjelasan guru, banyak yang sedang aktif berbincang-bincang dengan teman sebangku yang tidak berkaitan dengan kegiatan pembelajaran.

Hal tersebut merupakan sebuah indikasi siswa kurang termotivasi dalam belajar matematika. Masalah kurangnya motivasi belajar matematika ternyata tidak hanya terjadi pada siswa-siswa di sekolah-sekolah di Indonesia, tetapi fenomena ini juga terjadi di luar negeri seperti yang diungkapkan Sharon Andrews (Stone, 2009: 21) yang mengungkapkan bahwa murid-murid pada sebuah kelas dengan 28 orang murid kelas lima kelihatan mengantuk dan dengan wajah tanpa ekspresi dalam menghadapi pelajaran biologi. Hal senada juga dikemukakan oleh John P. Pieper yang mengungkapkan bahwa ketika murid-murid mulai mempelajari tentang mahluk hidup mereka memiliki sifat negative akan biologi. Ketika mereka naik kekelas lima, sebagian besar dari mereka benar-benar membenci biologi, sedangkan hanya beberapa yang menyukainya (Stone, 2009: 83).

Beberapa penelitian terkait sudah pernah dilakukan. Penelitian Fustika (2018) tentang pengembangan media layanan informasi karir berbasis google clasroom di Sekolah Menengah Kejuruan. Ada penelitian Maskar dan Wulantina (2019) tentang persepsi peserta didik terhadap metode blended learning dengan google clasroom. Kemudian penelitian Baban dan Sabara (2019) mengenai keefektivan google clasroom sebagai media pembelajaran. Selanjutnya ada penelitian Utami (2019) tentang analisis resfon siswa terhadap penggunaan google clasroom pada pembelajaran biologi. Penelitian tersebut relevan 
dengan penelitian yang sedang dikaji, tetapi memiliki perbedaan dimana penelitian ini khusus dilakukan pada mata pelajaran biologi dalam konteks motivasi belajar siswa. Oleh karena itu keberbedaan penelitian ini dengan penelitian tersebut di atas pada aspek motivasi sebagai bagian dari psikologi pembelajaran (Djaali, 2007; Hamalik, 2004; Prayitno, 1989).

Berdasarkan penjelasan tersebut di atas tujuan penelitian ini untuk meningkatkan motivasi belajar biologi siswa kelas XI IPS-1 SMAN 1 Masbagik dan mendeskripsikan peningkatan motivasi belajar biologi siswa kelas XI IPS-1 SMAN 1 Masbagik melalui E-Learning berbasis Google Classroom. Kondisi pandemic covid-19 yang mengharuskan menerapkan Pysical distencing sehingga pembelajaran tatap muka tidak bisadilakukan dan terpaksa pembelajaran dilakukan secara online (daring) dan masih rendahnya motivasi siswa dalam belajar biologi

\section{METODE PENELITIAN}

Dalam penelitian ini menggunakan metode penelitian tindakan kelas (PTK). Penelitian tindakan kelas adalah penelitian yang dilakukan peneliti didalam kelas, dengan tujuan untuk memperbaiki kinerja pengajaran sehingga hasil belajar meningkat (Narsim, 2015). Penelitian ini dilaksanakan di SMA Negeri 1 Masbagik Tahun Pelajaran 2020/2021. Subyek dalam penelitian tindakan kelas ini adalah siswa kelas XI IPS-1 SMA Negeri 1 Masbagik Tahun Pelajaran 2020/2021. Rancangan dalam penelitian ini mengacu pada model spiral atau siklus menurut Kemmis \& Mc Taggart. Tujuan menggunakan model ini adalah apabila pada awal pelaksanaan tindakan ditemukan adanya kekurangan, maka tindakan perbaikan dapat dilakukan pada tindakan selanjutnya sampai pada target yang diinginkan tercapai. Pada masing-masing siklus terdiri dari tahap perencanaan, pelaksanaan tindakan, observasi, dan refleksi. Penelitian ini dilaksanakan melalui 2 siklus. Masing-masing siklus terdiri dari perencanaan, pelaksanaan, observasi dan refleksi.
Sumber data berasal dari siswa kelas XI IPS1 SMA Negeri 1 Masbagik tahun pelajaran 2020/2021, guru mata pelajaran biologi tahun pelajaran 2020/2021, dan warga sekolah SMA Negeri 1 Masbagik tahun pelajaran 2020/2021. Jenis data yang diperlukan dalam penelitian ini adalah data kualitatif dan data kuantitatif. Data kualitatif diperoleh dari observasi pelaksanaan pembelajaran dan angket motivasi belajar, sedangkan data kuantitatif diperoleh dari data hasil belajar. Data-data yang didapatkan dalam penelitian ini yaitu; 1) Data hasil belajar siswa yang diperoleh dengan cara memberikan evaluasi belajar setelah akhir dari setiap siklus pembelajaran berlangsung; 2) Data motivasi belajar siswa yang diperoleh dengan cara memberikan angket motivasi belajar setelah akhir dari setiap siklus pembelajaran berlangsung; dan 3) Data tentang pelaksanaan pembelajaran didapat dari lembar observasi guru mengajar.

Instrumen yang digunakan dalam penelitian ini yaitu, lembar observasi. Observasi langsung berpedoman pada lembar observasi yang sudah disiapkan dengan memberikan ceklis sesuai deskriptor yang dilaksanakan oleh guru.Kegiatan ini, dilaksanakan pada saat proses pembelajaran berlangsung. Instrumen lainnya adalah angket dimana angket ini mengandung motivasi belajar yang dijabarkan dalam beberapa indikator, kemudian dari indikator-indikator tersebut dibuat butir pertanyaan-pertanyaan. Terakhir soal evaluasi dimana instrumen ini terdiri dari materi hasil belajar atas soal-soal yang telah disesuaikan dengan silabus dan materi yang telah disampaikan sebelumnya oleh guru mata pelajaran di sekolah, kisi-kisi soal yang dibuat disesuaikan.

Data yang dianalisis adalah data motivasi belajar siswa, skor motivasi yang diukur dalam penelitian ini menggunakan angket model ARCS. Perhitungan skor yang diberikan siswa terhadap pernyataan-pernyataan dalam angket motivasi siswa dibuat dengan ketentuan sebagai berikut:

a. Untuk pernyataan dengan kriteria positif

$1=$ Tidak Pernah

$2=$ Jarang

$3=$ Kadang-kadang 


\section{$4=$ Sering}

$5=$ Selalu

b. Untuk pernyataan dengan kriteria negatif

$1=$ Selalu

$2=$ Sering

$3=$ Kadang-kadang

4= Jarang

5=Tidak Pernah

(Walgito, 2004)

Setelah memperoleh hasil tes belajar, data tersebut dianalisis dengan mencari ketuntasannya baik secara individu maupun klasikal. Ketuntasan belajar secara individu apabila siswa mampu memperoleh nilai $\geq 75$. Adapun ketuntasan klasikal dihitung dengan ketentuan ketuntasan klasikal.

$$
K K=\frac{X}{Z} x 100 \%
$$

Keterangan:

\section{KK : Ketuntasan Klasikal}

$X$ : Jumlah siswa yang memperoleh nilai $\geq 75$

Z: Jumlah siswa yang ikut tes

(Nurgiantoro, 2009).

Sesuai dengan petunjuk teknik penilaian kelas dapat dikatakan tuntas secaraklasikal terhadap prestasi belajar yang disajikan bila ketuntasan klasikal mencapai $\geq 85 \%$. Penelitian ini berhasil apabila motivasi belajar biologi siswa mengalami peningkatan rata-rata motivasi dengan kategori minimal cukup baik dan juga prestasi belajar mengalami peningkatan dari siklus satu ke siklus selanjutnya.

\section{HASIL DAN PEMBAHASAN}

\section{Hasil Penelitian}

\section{Siklus 1}

Pelaksanaan Pembelajaran (RPP), menyiapkan LKS pembelajaran, menyiapkan soalsoal kuis untuk mengukur ketercapaian indikator pembelajaran, menyiapkan lembar observasi

\section{berbasis Google Classroom.}

\section{Pertemuan Pertama}

Adapun materi yang akan di ajarkan pada praktik pembelajaran tersebut adalah system pernapasan pada manusia. Pada tahap akhir pembelajaran guru memberikan pekerjaan rumah dan tugas kepada siswa untuk mempelajari materi yang akan disampaikan pada pertemuan selanjutnya yang berkaitan sistem pernapasan pada manusia berbasis google classroom.

2. Pertemuan kedua

Pada kegiatan awal pembelajaran, diawali dengan dengan membuka pelajaran dilanjutkan dengan mencocokkan PR dan dilakukan pembahasan mengenai soal yang sulit. Tujuan pembelajaran kali ini adala menjelakan bahaya rokok bagi kesehatan. Pada tahap akhir pembelajaran guru memberikan pekerjaan rumah dan tugas kepada siswa untuk mempelajari materi yang akan disampaikan pada pertemuan selanjutnya berbasis Google Classroom.

\section{Pertemuan Ketiga}

Tujuan pembelajaran kali ini adalah menjelaskan pengaruh pencemaran udara terhadap system pernapasan. Pada pembelajaran dipertemuan ketiga ini siswa dipersilahkan kembali untuk belajar dan berdiskusi.Sesuai dengan waktu yang ditentukan siswa dipersilahkan untuk mengumpul hasil pekerjaan mereka masing-masing, selanjutnya yang dilakukan guru adalah menyebar angket motivasi belajar untuk mengetahui sejauh mana motivasi belajar yang di alami siswa setelah dilaksanakn E-Learning berbasis Google Classroom. Untuk mengakhiri pelajaran guru menginformasikan materi yang harus dipelajari pada pertemuan selanjutnya yaitu gangguan system pernapasan. Guru memberikan tugas kepada seluruh siswa untuk mempelajari materi tersebut. 


\section{Observasi}

Pelaksanaan pembelajaran yang dilakukan oleh guru dan peneliti bertindak sebagai observer dengan menggunakan lembar observasi. Hasil pengamatan pelaksanaan pembelajaran pada siklus I memperoleh skor 46 yang berada dalam kategori cukup baik.Hasil evaluasi yang diperoleh oleh siswa setelah pelaksanan E-Learning berbasis Coogle Classroom dapat dilihat pada lampiran hanya $20,00 \%$ siswa (6 siswa) yang sudah tuntas dan sisanya sebanyak $80,00 \%$ (24 siswa) belum memenuhi standar ketuntasan yang ditetapkan yakni 75.Hasil motivasi belajar siswa yang didapat dari angket yang disebar menunjukkan $61,76 \%$ tinggi, dan $38,24 \%$ sedang.

\section{Refleksi}

Refleksi pada siklus I dilakukan dengan mengkaji hasil observasi serta permasalahan yang dihadapi selama tindakan pada siklus I berlangsung. Pada siklus I siswa belum dapat mengikuti proses pembelajaran dengan maksimal. Penguasaan siswa terhadap materi yang diajarkan dengan E-Learning berbasis Google Clasroom juga masih rendah yaitu rata-rata siswa hanya mendapat nilai 65,82 dimana masih jauh dari kriteria ketuntasan belajar yang ditetapkan. Ditinjau dari segi guru, masih banyak yang perlu ditingkatkan antara lain dalam halapersepsi dan motivasi, urutan penyajian materi, keterlibatan siswa, bimbingan kepada siswa sebagai fasilitator, penghargaan tim dan juga pengembangan keterampilan siswa yang masih mendapat penilaian 2 (keterlaksanaannya cukup baik). Masih rendahnya keterlaksanaan pengelolaan pembelajaran yang dilakukan guru dengan E-Learning berbasis Google Classroom merupakan salah satu penyebab rendahnya hasil evaluasi belajar siswa (Hakim, 2016).

\section{Siklus II}

\section{Perencanaan dan Persiapan Tindakan}

Perencanaan dan persiapan tindakan yang dilakukan peneliti berdasarkan hasilrefleksi pada siklus I. Proses pembelajaran masih tetap menggunakan E-Learning berbasis Google
Classroom meliputi;

1. Menyusun Rencana Pelaksanaan Pembelajaran (RPP), Menyiapkan LKS pembelajaran.

2. Menyiapkan soal-soal kuis untuk mengukur ketercapaian indikator pembelajaran.

3. Menyiapkan lembar observasi pembelajaran.

4. Menyiapkan angket motivasi pembelajaran

\section{Pelaksanaan Tindakan}

\section{Pertemuan Keempat}

Materi pembelajaran yang akan disampaikan adalah gangguan system pernapasan berbasis Google Classroom. Sebelum pembelajaran dimulai guru mengabsen siswa, menanyakan kabar siswa dan kesiapan mereka dalam mengikuti pelajaran. Guru juga menginformasikan hasil dari kuis individu dan skor perkembangan rata-rata yang diperoleh pada pertemuan sebelumnya berbasis Google Classroom. Setelah guru menginformasikan tujuan pelajaran yang akan dicapai, dan menyampaikan materi siswa kembali ditugaskan untuk bekerja melaui LKS berbasis Google Clasroom. Siswa menyimpulkan materi yang disajikan di LKS. Kuis individu diberikan untuk mengukur ketercapaian indikator yang menjadi tujuan pembelajaran. Pada tahap akhir pembelajaran guru memberikan tugas kepada siswa untuk mempelajari materi yang akan disampaikan pada pertemuan selanjutnya pembelajaran diakhiri dengan salam.

\section{Pertemuan kelima}

Pembelajaran dimulai dengan salam, mengecek kehadiran, dan menyiapkan peserta didik untuk mengikuti pembelajaran selanjutnya. Setelah guru menginformasikan tujuan pembelajaran yang akan dicapai, dan menyampaikan materi siswa kembali ditugaskan mengerjakan soal melaui LKS yang diberikan di Google Clasroom. Setelah selesai mengerjakan, siswa kemudian menyimpulkan materi pelajaran pada hari itu. Siswa kemudian mengerjakan kuis individu dan juga mengisi angket motivasi belajar. Pelajaran diakhiri dengan salam. 


\section{Observasi}

Pengamatan terhadap proses pembelajaran dilakukan oleh peneliti yang bertindak sebagi observer. Instrument yang digunakan berupa lembar observasi terhadap guru mengajar seperti yang digunakan pada siklus I. Pengamatan pelaksanaan pembelajaran pada siklus II memperoleh skor 59 yang berada dalam kategori sangat baik.Selainmelakukan pengamatan terhadap guru, juga dilakukan pengamatan terhadap keberhasilan siswa dalam belajar dan motivasi belajar siswa. Pelaksanaan pengamatan proses pembelajaran pada siklus ini, siswa sebagian besar antusias mengikuti pembelajaran. Hasil evaluasi yang diperoleh oleh siswa setelah pelaksanan $E$ Learning berbasis Google Classroom dapat dilihat pada lampiran. Sebanyak80,00 \% (24 siswa) dianggap sudah tuntas dan sisanya sebanyak $20,00 \%$ (6 siswa) belum memenuhi standar ketuntasan yang ditetapkanya kni 75 . Nilai rata-rata persentase ketuntasan kelas menunjukkan peningkatan yang signifikan dari siklus I yaitu dari 58,00 menjadi 72,94. Hasil motivasi belajar siswa yang didapat dari angket yang disebar menunjukkan persentase rata-rata sebesar $72,4 \%$ targolong sedang.

\section{Refleksi}

Refleksi pada siklus II dilakukan dengan mengkaji hasil observasi serta permasalahan yang dihadapi selama tindakan pada siklus I berlangsung. Pada siklus II siswa sudah mulai dapat mengikuti proses pembelajaran. Penguasaan siswa terhadap materi yang diajarkan dengan $E$ Learning berbasis Google Classroom juga sudah mulai meningkat. Hasil belajar yang ditunjukkan melalui nilai persentase ketuntasan rata-rata kelas menunjukkan peningkatan signifikan dari siklus I yaitu dari 58,00 menjadi 72,94. Ditinjau dari segi motivasi belajar biologi siswa sudah baik hal tersebut dapat dilihat dari data yang menunjukkan bahwa rata-rata motivasi belajar siswa menunjukkan peningkatan yang signifikan dari $66,3 \%$ menjadi $72,4 \%$, Hal tersebut merupakan tantangan bagi guru agar dapat mengelola proses pembelajaran lebih baik lagi untuk dapat meningkatkan motivasi belajar siswa agar lebih baik lagi. Secara spesifik motivasi belajar siswa yang masih perlu ditingkatkan adalah berkaitan dengan dorongan dan kebutuhan dalam belajar siswa dan lingkungan belajar yang kondusif (Hogan, 2002).

\section{PEMBAHASAN}

Pembelajaran biologi di SMA Negeri 1 Masbagik sebelum masa pandemic covid-19 dilakukan secara konvensional, masih didominasi oleh guru, proses pembelajaran dimana guru menyajikan pengetahuan matematika kepada siswa, siswa memperhatikan penjelasan dan contoh yang diberikan oleh guru, kemudian siswa menyelesaikan soal-soal sejenis yang diberikan guru, jarang memberi penghargaan kepada siswa dan juga belum tersedianya bahan ajar yang sitematis. Motivasi siswa juga rendah karena perhatian siswa kurang, respon siswa rendah dan aktivitas siswa kurang. Salah satu usaha yang dapat dilakukan untuk dapat melibatkan siswa lebih-lebih di masa pandemic covid-19 dan melakukan prinsip Social Distancing adalah melalui E-Learning berbasis Google Classroom.

Penggunaan Google Classroom sebagai media pembelajaran memungkinkan memberikan dampak yang positif terhadap peningkatan motivasi belajar dan prestasi belajar. Penggunaan Google Clasroom memberikan dampak yang layak sebagai media pembelajaran. Penelitian tindakan kelas ini dilakukan dalam dua siklus dengan menggunakan model E-Learning berbasis Google Classroom. Berdasarkan hasil analisis tindakan dan hasil evaluasi pada siklus I diketahui bahwa ketuntasan belajar belum mencapai seperti yang diharapkan. Hal ini ditunjukan oleh hasil evaluasinya yaitu persentase ketuntasannya adalah $50,00 \%$, , sehingga sebelum melanjutkan pembelajaran ke siklus berikutnya dilakukan upaya perbaikan dan penyempurnaan terlebih dahulu dengan melakukan pembimbingan siswa yang mendapat nilai kurang dari 75 dengan bimbingan secara khusus atau individual. Adapun hasilnya adalah dengan lebih 
termotivasi dan antusiasnya siswa dalam bertanya baik kepada temannya maupun kepada guru. Dan juga dapat terlihat pada saat siswa mengerjakan soal-soal latihan setelah berdiskusi dan diberikan bimbingan. Tindakan yang akan dilakukan untuk memperbaiki kekurangan yang ada pada siklus I yaitu: guru harus memberikan motivasi yang lebih mengarah pada manfaat belajar pada pokok bahasan yang bersangkutan, berusaha mengarahkan siswa untuk mengerjakan tugas rumah untuk dikumpulkan pada pertemuan berikutnya agar mereka ada persiapan dari rumah, mengontrol dan mengawasi siswa dalam mengerjakan LKS, memancing siswa untuk membangkitkan pertanyaan maupun menjawab pertanyaan, dan penyampaian materi harus menyesuaikan dengan daya serap siswa berbasis Google Clasroom.

Setelah dilakukan tindakan pada siklus II yang mengacu pada perbaikan tindakan dari siklus I diperoleh hasil yang lebih baik. Langkah-langkah dalam penyelesaian soal sudah urut. Ini ditunjukkan dari hasil evaluasi akhir siklus dimana persentase ketuntasan adalah $80,00 \%$. Perbandingan nilai awal siswa yang didapat dari hasil ulangan harian dan nilai ulangan tengah semester dengan nilai yang didapat pada kuis individu tidak jauh beda, kecuali kuis I nilai rataratanya di bawah nilai awal namun nilai rata-rata kuis individu setiap kali diadakan kuis setelah pembelajaran mengalami peningkatan. Dari segi motivasi belajar siswa yang merupakan fokus utama dalam penelitian tindakan kelas ini dengan menggunakan model E-Learning berbasis Google Classroom yang dilaksanakan dalam dua siklus, menunjukkan dari sikulus I dan siklus II rata-rata mengalami peningkatan, walaupun tidak besar.

Pada siklus I rata-rata motivasi belajar adalah 66,3\% sedangkan pada siklus II naik menjadi $72,4 \%$. Untuk butir pertanyaan dalam angket motivasi butir 6 sampai 9 perlu dilakukan peningkatan baik siklus I maupun siklus II menunjukkan hasil berturut-turut $55,3 \%$ dan $65,3 \%$ masih paling rendah dari indikator-indikator yang lain. Dengan keadaan ini peneliti menyarankan kepada semua guru biologi untuk lebih mengelola pembelajaran, memotivasi siswa untuk lebih rajin, menumbuhkan semangat belajar, gemar berkunjung ke perpustakaan sehingga memungkinkan peningkatan motivasi belajar siswa untuk mendapatkan hasil belajar yang lebih baik.

Jika mengacu pada pemahaman bahwa secara psikologi dalam konteks pembelajaran, maka kedua model di atas dapat membrikan stimulus bagi peningkatan motivasi belajar siswa. Hal ini berkaitan erat dengan konsep psikologi tentang meotivasi dimana harus ada berbagai terobosan dilakukan dan upaya yang inovatif jika motivasi ingin terus dan tetap ditingkatkan (Sardiman, 1992; Slameto, 2003; Uno, 2008). Hal ini penting sebagai upaya guru dalam meningkatkan gairah siswa dalam proses pembelajaran terutama pelajaran biologi.

\section{KESIMPULAN}

Motivasi belajar biologi lintas minat siswa kelas XI IPS 1 di SMAN 1 Masbagik melalui $e$ lierning berbasis google classroom mengharuskan siswa menerapkan physical disttencing dan tidak bisa dilakukan secara tatap muka. Keterlaksanaan e-learning berbasis google classroom pada siklus I pada kategori baik dan pada siklus II pada kateori sangat baik. Motivasi belajar biologi siswa kelas XI IPS-1 SMA Negeri 1 Masbagik mengalami peningkatan pada siklus I rata-rata motivasi belajar adalah $66,3 \%$ dalam kategori rendah sedangkan pada siklus II naik menjadi $72,4 \%$ dalam kategori sedang. Hasil belajar Biologi siswa SMA Negeri 1 Masbagik dengan e-learning berbasis google classroom dari siklus I dan siklus dua mengalami peningkatan yang signifikan yaitu dari $50,00 \%$ siklus I ke $80,00 \%$ siklus II.

\section{SARAN}

Pembelajaran biologi di saat pandemic covid-19 hendaknya menggunakan model $E$ Learning dengan teknik, metode, strategi atau pendekatan yang bervariasi sehingga motivasi belajar dan hasil pembelajaran dapat lebih maksimal. Mengingat pelaksanaan Penelitian Tindakan Kelas (PTK) ini hanya dua siklus, dan 
validasi instrumennya belum standar, maka kepada guru yang akan melakukan penelitian implementasi E-Learning berbasis Google Classroom dalam proses pembelajaran diharapkan dapat lebih ditingkatkan kualitasnya, baik frekuensinya maupun instrument penelitiannya. Bagi para pengajar, lebih-lebih disaat pandemi covid-19 hendaknya membiasakan diri menggunakan $E$ Learning seperti Google Classroom agar mempermudah pembelajaran dan dapat meningkatkan pemahaman siswa serta siap dalam menghadapi perubahan perkembangan Pendidikan di abad ke-21.

\section{Ucapan Terima Kasih}

Ucapan terima kasih kami sampaikan kepada Bapak kepala sekolah SMA Negeri 1 Masbagik yang telah memberikan waktu untuk dapat melaksanakan penelitian tindakan kelas ini. Bapak Ibu/Guru yang telah banyak mendukung dan memberikan saran atas pelaksanaan penelitian ini sehingga terlaksana dengan baik dan lancar.

\section{DAFTAR PUSTAKA}

Fustika, A. (2018). Pengembangan Media Layanan Informasi Karir Berbasis Google Clasroom di Sekolah Menengah Kejuruan. J. Pendidik dan Pembelajaran. 8(12), 1-9.

Maskar, A. and E. Wulantina. (2019). Persepsi Peserta Didik terhadap Metode Blended Learning dengan Google Clasroom. J. Inov. Mat, 1(2), 110-121.

Alam, F. (2012). Pembelajaran Jarak Jauh. Bandung: Alfabeta.

Arends, Richard I. (2008). Belajar untuk Mengajar. (Terjemahan Helly Prajitno Soetjipto \& Sri Mulyantini Soetjipto). Yogyakarta: PustakaPelajar.

Baban dan Sabara (2019). Keefektivan Google Clasroom Sebagai Media Pembelajaran. Proos. Smins. Nas. Penelit. UNM, 122-125.
Walgito, Bimo (2004). Bimbingan dan Konseling (Studi dan Karier). Yogyakarta: Andi

Nurgiantoro, Burhan 2009. Statistik (Ketuntasan Klasikal). Jakarta. RinekaCipta.

Djaali, H. (2007). Psikologi Pendidikan. Jakarta: BumiAksara.

Hakim, A. B. (2016). Efektivitan Penggunaan ELearning Moodle, Google Clasroom dan Edmodo. I-STATEMENT. 2(1), 1-6.

Hogan, R. and B.W. Roberts. (2002). Personality Psychology. Woshington: American Psychological Assosiation.

Narsim (2015). Penelitian Tindakan Kelas. Semarang: Sinar Terang.

Hamalik, Oemar. (2004). Psikologi Belajar dan Mengajar. Bandung: Sinar Baru Algensindo.

Prayitno, Elida. (1989). Motivasi Dalam Belajar. Jakarta: Depdikbud

Sardiman, A. M. (1992). Interaksi dan MotivasiBelajarMengajar. Jakarta: PT Raja grafindo Persada.

Slameto. (2003). Belajar dan Faktor-Faktor yang Mempengaruhinya. Jakarta: Rineka cipta

Stone, Randi. (2009). Cara-cara Terbaik Mengajarkan Matematika. (Terjemahan Suci Romadhona). Jakarta: PT Macanan Jaya Cemerlang.

Uno, Hamzah B. (2008). Teori Motivasi dan Pengukurannya Analisis di Bidang Pendidikan. Jakarta: Bumi Aksara.

Utami, A. (2019). Analisis Resfon Siswa Terhadap Penggunaan Google Clasroom Pada pembelajaran Biologi. Prims. Pross. Smins. Nas. Mat, 2, 498-502. 